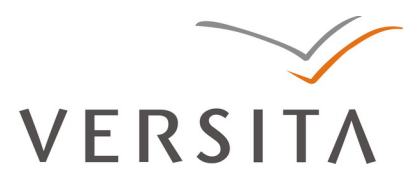

DOI: 10.2478/genst-2013-0019

\title{
FAMILY AND SOCIAL LIFE
}

\author{
REMINA SIMA \\ Henri Coanda College, Timişoara \\ 37, I.C. Brediceanu, Timişoara \\ reminasima@yahoo.com
}

\begin{abstract}
The paper deals with the concept of family seen both as a system and as a unit. It shows how family functions and the structure of family. The paper also draws attention to the separation between home and work which makes substantial differences to the daily lives of both men and women. This means that there is a clear distinction between working time and leisure time, and there is a much clearer distinction between public and private life.
\end{abstract}

Keywords: education, family, oikos, polis

\section{Introduction}

It is possible to observe family life or even to be part of family life and yet to be limited in one's understanding of it, because our vision is limited. Active involvement in family life may be the very reason we fail to understand 
it from a wider perspective. When talking about the issue of family, Jack and Judith Balswich approach it by taking into account two theoretical perspectives. The first is called family-systems theory, while the second is family development theory. The former theory views family life as the interactions of all family members acting as a unit. The latter views the family as developing over time.

When discussing the first theory, the authors talk about individualism. This madepeople focus on the individual's needs and perspectives, rather than on relationships and groups. Within contemporary research, the balance between individual rights and family rights has been tilted in favour of individual rights. Nevertheless, there now seems to be a tendency to shift the focus from the individual to the wider family system.

The authors present the family-systems perspective to us as a holistic approach that sees the family as a whole. A system is defined as an identifiable whole which is composed of interrelated individual parts. In order for the system to be understood, one must begin by identifying the boundary around it. In Western cultures this is drawn around the husband and wife and their children. In other cultures, it also includes their relatives. In the newly established family there are two individuals, the husband and the wife, each with an identifiable position and role within the family. Once children come into the family, the system becomes more complex as each new member occupies a given position in the system as he/she is assigned a role to play in it. In fact, in a family which includes children we may talk about subsystems.

The second theory shows us the typical family's progression through various stages of life. The family is dynamic rather than static. The authors state 
that within each stage there are certain key developmental tasks that the family must accomplish in order to progress to the next stage. To the extent that both the family as a unit and individual family members master their respective tasks, the family is prepared to move on to the next stage of development. A family is said to have moved from one stage to the next when a major transition takes place. The first stage would be the premarital one, because of the importance of differentiation from the family into which a person was born. This process of differentiation actually begins in adolescence and should be completed during the engagement period. The most obvious transition in the lifecycle is marriage. When two people marry, a new family begins in the form of a dyad. The major developmental task involves the husband's and wife's adjustments to each other in their new roles as married rather than single persons. In this stage the newly formed family must start by setting up a new household, dividing up household chores, establishing work and career roles, developing friendships, planning social events and so on.

The next stage is when children are born into the family, followed by their childhood and adolescence. In this stage children are differentiating from the family. Then comes the stage when children choose their careers and marriage partners. is when the last child leaves home and the parents have to learn to accept years of aloneness and the aging process(Jack O. and Judith K. Balswich 1997:35-43)

\section{The Polis versus the Oikos}

Interest has been shown in studying the family ever since early times. The modern family, belonging to the private sphere, should not be debated 
without taking into account the public sphere as well. The Greeks made a clear distinction between the polis on the one hand and the oikos or family on the other.

In the Republic, Plato understands and accepts this distinction between public and private. As Plato's ideal Republic was to set out to eliminate the private sphere altogether, he needed to find a role for the women who had previously filled the role of wives in the private sphere. Plato considers that men and women should be trained equally for the role of a ruler. Plato's Republic is a form of discourse which emerged from a setting that not only excluded women but included relationships between dominant men. Rather than consigning women to particular social outcomes based on chronological categories, Plato insists that one may find within the category of women gifted individuals who possess all the qualities necessary to become a guardian. Such unique women can undertake the same training as their male counterparts, for if these women are available for the same tasks as men, they must also be taught the same things. Plato does not seem to encourage a social order in which individuals are evaluated and placed according to some a priori assessment of their higher or lower potential; the fact that people are born into a social class or biological sex does not in itself amount to evidence that a member of one particular class has a higher or lower nature than anyone else. Plato requires that all considerations of sex, race, age, class, tradition and history be stripped away in order for people to be fitted into their appropriate social slots, performing functions to which they are suited. Should a male or female possess an aptitude for a particular occupation, for the female to enter that occupation along with a similarly qualified man constitutes no violation of wisdom. 
So Plato would educate women in the same way as men, for otherwise they will lack that common purpose without which the state is doomed to be but half a state. Plato's motive for equal education of the sexes was not some mere consideration of social justice or equality or individual rights, but a means to his overriding end: social harmony and unity. (Elshtain 1997:24-37).

Aristotle sees women as completely within the oikos or household; he denies woman any possibility of a public voice or role and recommends female self-transformation over time. He constructed this arrangement under the terms of a set of teleological presumptions and an explanatory theory flowing from those presumptions that was to have major consequences for women, men and politics. For Aristotle, each separate thing is predetermined; it is designed to fulfill its essence. He assumes that one can determine what a thing, person, or institution is in terms of its functionalist framework; each thing's purpose is to fulfill functions it alone can fulfill. Although familiar with Plato's argument that women's nature cannot be assigned a public dimension, Aristotle remains unmoved. Although he is often contrasted with Plato and seen as a defender of diversity and a friend of pluralism, he is categorically inflexible on some issues. Woman's nature and her consequent function is one of these. Women, children and slaves did not and could not partake in the full unfolding of goodness and reason. There is an essential difference between greater (free male) and lesser (unfree female) persons, although these two categories of persons are in relationships of dominance and subordination. Aristotle justifies this relationship by finding a common interest between the naturally ruling element and the element that is naturally ruled. 
The household constituted a nonpublic sphere within which the female was subsumed and which therefore defined her. The good at which the household aimed was a lesser good than that which was the end of both. The wife-mother achieved only the limited goodness of the naturally ruled, a goodness different from that of the naturally ruling. Public persons, by definition, were responsible, rational and free. They acted both in private life and in the life of the polis. As exclusively private persons, not fully rational, women lived out their lives in the realm of necessity, a life deemed inferior in its essence and purpose to political life but a functional prerequisite for the realm of freedom. (Elsthain 1997:41-47).

Within the family and in certain social contexts women exercised real power. They also wielded compensatory or supplementary powers. Law extends certain protections to women but it also limits their actions. The Germanic tribes who settled in the Roman Empire brought with them a variety of legal systems. These laws are very strict when it comes to women's rights and obligations. In A History of Women, Suzanne Fonay Wemple discusses the diversity of laws from late Antiquity to the Carolingian period. She demonstrates how the main cells of society related to one another. It is very important to understand this, as it will lead to an understanding of the relations between the sexes, individuals and the public sphere. Within Medieval Europe, marriage was seen as a transition between childhood and adult life and it became a sacrament of the Church between the $11^{\text {th }}$ and the $12^{\text {th }}$ centuries.

The status of women in the Middle Ages can be regarded in different ways depending on the emphasis that is laid on its legal, economic and demographic aspects. Suzanne Fonay Wemple asserts that women's position 
improved considerably under the Roman Empire. She gives a brief description of the Roman Empire, regarding which she states that it began to decline when its social and economic systems began to break down. The civil wars of the $3^{\text {rd }}$ century and attacks from outside accelerated the process on account of the increase in economic troubles in the countryside and the cities. Little by little, the Empire became a dictatorship, having ceased to be a community of city states In the $3^{\text {rd }}$ century, the Empire was divided in half. The military and civil commands were separated, and the army was now made up of men of Germanic origin. In the $4^{\text {th }}$ century, Constantine embraced Christianity, gave great importance to the religion of the Empire and reconsidered Augustus's marriage laws while allowing unmarried women to have control over their possessions and property.

Within this historical background of the Roman Empire there was a growing custom in many marriages for the goods of the woman not to be transferred to her husband. This represented a step towards female emancipation. When women attained their majority, they could control their own property and marry whenever they wanted, but their freedom of action continued to be restricted when it was a case of getting a divorce. Although Christianity did not end sexual discrimination in the late Roman Empire, it offered women the opportunity to regard themselves as independent persons and not as someone's daughter, wife or mother. In line with the Acts of the Apostles, women were enabled to develop self-esteem as human beings who possessed the same potential for perfection as men.

In terms of education, some women, and not only monks, could enjoy this during iddle Ages. Suzanne Fonay Wemple mentions three such highly 
educated women. One was Amalasuntha, daughter of Theodosius the Great, the Ostrogothic king of Italy; the second was Eucheris, who was married to the governor of Marseilles and the third was Dhuoda who wrote Liber Manualis that reflects her love for her husband and four sons.

Women who wanted to enjoy intellectual life had great opportunities for education. Religious communities provided a suitable environment and a quiet atmosphere where women could work and pray. In serving God and each other in humility, they could participate in the liturgy and find an outlet for their administrative and intellectual talents. Some women worked as librarians, scribes or teachers. Books and teachers were needed to educate children.. The oppression of women in the Middle Ages was somewhat abated. (Duby and Perrot 1992:170-200).

Paulette L'Hermite-Leclerq describes women's status in the $11^{\text {th }}$ and $12^{\text {th }}$ centuries, the time when the church gave marriage its modern form. Marriage became a sacrament, but until the $12^{\text {th }}$ century the content of that sacrament had been vague. There was a need for clarification so that marriage could be included on the official list of sacraments promulgated by the church in the year 1215. Of the seven sacraments, marriage was the only one mentioned in law: the first man and the first woman had been joined in marriage. Marriage was the foundation of all of human society and it transformed the binary relation between men and God into a tertiary relation: God, man and woman.

Life at home was influenced by one's legal and economic status and social rank. Women's dowries and settlements were also very important. In rural areas, women had great responsibilities and authority that contributed in a 
significant way to the family's productivity. Women were in charge of storing the harvest, of growing vegetables and of maintaining the hearth. Thus, women were autonomous, but they were still not considered to be men's equals. On account of the fact that the whole of their dowries and half of all property acquired after marriage belonged to them, they could participate in all their husbands' real estate transactions. L'Hermite Leclerq states that despite our lack of information concerning family life in the period, there was certainly a revival of urban life andwomen doing the same work in the city as men were paid less during the period that concerns us (Duby and Perrot 1992: 202-231).

Finally, I shall refer to the period of the late Middle Ages. In Europe, medieval society was generally masculine in character. Its culture reflected the dominance and power struggles of men. Nevertheless, there was one great figure of that time who was concerned with women's issues. Christine de Pizan is a remarkable woman who lived at a time when women were smothered by male prerogative. She is represented in glowing terms by Reghina Dascăl in her outstanding Christine de Pizan Essays. She lived between 1364 and 1431, and throughout her life she advocated women's rights, fighting against misogyny at a time when it was not a common thing to do so. Professor Dascăl asserts:

For a woman to write for a wide audience and to deal specifically with the subject of women was extremely rare in that century. Despite the complex nature of the society of those days, its female half was identified according to a value system and a hierarchy set up by the male half. Christine de Pizan dealt with the subject many times (Dascăl 2008:19). 
Christine de Pizan even taught the reader how texts should be read so as to derive moral edification and spiritual truth from them. She defended women's right to take an equal part in intellectual work. She herself succeeded in becoming what is now called a career woman. Sappho in Ancient Greece was the first woman to publish under her own name, followed by Christine de Pizan. Christine was an intelligent and enterprising woman who made a living by her pen, something that was almost unknown for a woman in that historical period (Dascăl 2008:20-23).

\section{Conclusion}

Everybody finds herself/himself oscillating between the two spheres that I have discussed throughout my paper. I do not intend to set one above the other; on the contrary, I consider them both of outstanding importance for everyday life. In order for somebody to cross the boundaries of the private sphere, it is necessary that he/she should take into consideration the issue of education, by means of which we can develop our activities. Fortunately, much progress has now been made as regards women's access to civic society. The old barriers are falling one after the other and women are no longer restricted in their choice of a profession, nor are they denied opportunities of advancement in any field they may select. Therefore, the part they play in public life depends entirely on themselves.

\section{References:}

Balswick, Jack O. and Balswick, Judith K. 1997. Family - a Christian Perspective on the Contemporary Home. Grand Rapids: Baker Book House. 
Dascăl, Reghina. 2008. Christine de Pizan Essays. Timişoara: Editura Universităţii de Vest. Duby, George and Perrot, Michelle. 1992. A History of Women in the West. Silences of the Middle Ages. London: Harvard University Press.

Elshtain, J.B. 1997. Public Man, Private Woman - Women in Social and Political Thought. New Jersey: University Press. 